\title{
ANALISIS PEMIKIRAN HENRI LEVEBVRE TENTANG RUANG DALAM ARSITEKTUR MODERN: SUATU PERSPEKTIF SOSIOLOGIS
}

\author{
Oleh: Djaja Hendra*
}

\begin{abstract}
This article was trying to understand Henri Lefebvre's thinking about space. Space means not what scientists think. Is space the same as everyday life, or is it different. Then, space means what and where Lefebvre pours space in his thoughts. What does Lefebvre mean about modern architecture and what is the diffence with traditional architecture and what kind of space to place in both types of architecture. Who are the characters close to Lefebvre and who are the figures he influences. Concerned, the figures who are also the thinkers, Lefebvre inti the camp of where and who most preferred his thoughts ranging from classical sociologist and modern sociology and the reasons he put forward.
\end{abstract}

Keywords: Architecture Modern, Space, Lefebvre, Sociology.

\section{Pendahuluan}

Henri Lefebvre adalah seorang idealis, bukan oportunis. Lefebvre mempunyai rekan sekoleganya seperti: Marcel Mauss, Walter Benjamin, Norbert Elias, Michel Foucault, Ernst Bloch, Siegfried Kracauer, Pierre Bourdieu, Maurice Halbwachs, Karel dan sosiolog lainnya (http://en.wikipedia.org/wiki/Sociolo gy_of_architecture\# ClassicalSociology_of_architecture). Banyak gagasannya yang dipakai para pemikir di awal pertengahan abad ke20 yang baru lalu. Dalam gagasannya itu, banyak pemikir memanfaatkan konsep - konsep dan teori - teori yang dikemukakan, untuk membahas banyak hal terutama berkaitan dengan fenomena sosial. Sudut pandangnya sungguh menarik untuk disimak dan dicermati dengan lebih mendalam dan saksama.

Dalam tulisan - tulisannya yang cukup banyak, para pemikir kebingungan dalam menempatkan Lefebvre ke kubu mana. Tujuannya, tidak lain untuk memudahkan pembahasan dan penganalisisan dalam kaitan dengan fenomena sosial tadi. Acapkali para pemikir menempatkan Lefebvre masuk ke 
dalam kubu Weber. Lihat saja, analisisnya tentang habitus, doxa, arena (field) dan seterusnya. Artinya, dia dapat dimasukkan ke dalam sosiologi mikro; yang menempatkan para pemikir termasuk Lefebre ke dalam bentuk - bentuk yang relatif lebih kecil atau batasan yang rendah. Kadang - kadang dia bisa juga mengulas masalah globalisasi, negara, kelembagaan, dan analisis struktural maupun jaringan dan seterusnya. Dalam kapasitasnya yang beraneka, tidak jarang pula para pemikir memasukannya ke dalam kubu neo-Marxian. Tetapi alasan yang paling masuk akal, bagi yang cermat, teliti, dia dengan segala kesiapannya masuk ke dalam kubu Marx. Kenapa demikian?

\section{Soalnya,} dengan menempatkan ruang sebagai salah satu objek kajian dan analisis yang dilakukannya, lebih tepat kalau Lefebvre masuk ke kubu Marx. Dalam hal ini, ruang, kata Lefebvre, selalu bergerak dan bukan tetap (ajeg). Secara demikian maka wajar saja para pemikir menempatkan Lefebvre masuk ke dalam kubu Marx; sementara yang lainnya dimasukkan ke dalam kubu yang berseberangan dengan Lefebvre. Jika Lefebvre merupakan pemikir yang keberikut maka di belakangnya akan diikuti pula oleh para pemikir yang lain sebagai pengagum dan sebagai idolanya. Ruang, dalam konteks ini, kata Lefebvre selalu dinamis seirama dengan tumbuhan, batuan, musik, dan lain sebagainya yang hidup; sebagai bentuk-bentuk lain dari konsep-konsep pemikiran, yang nantinya akan dipergunakan Lefebvre dalam menyikapi kehidupan sosial.

\section{Ruang Sebagai Produk Sosial}

Ruang, jika begitu sangat dinamis, luas dan mendalam sifatnya. Ruang, tidak dapat dilihat secara kasat-mata begitu saja melainkan terdapat dimensi - dimensi lain yang turut menyertai, sehingga tidak setiap pemikir dapat mencermati dan memahami secara bijak dan benar. Paling tidak, yang dilakukan para pemikir, sebagaimana yang dipersepsikan. Padahal ruang tidak seperti itu. Kata Lefebvre, ruang memiliki beberapa tingkatan, dari yang paling abstrak, terlihat dengan mata telanjang, dan ruang alamiah (ruang absolut) menuju ruang yang lebih kompleks dan maknanya 
diproduksi secara sosial (social space). Argumen Lefebvre dalam bukunya, The Production of Space adalah ruang sebagai produk sosial, atau konstruksi sosial yang kompleks (berdasar nilai dan produksi sosial atas makna) yang mempengaruhi praktik ruang dan persepsi atas ruang. Sebagai filsuf marxis (namun sangat kritis pada strukturalisme yang menjadi wacana dominan masa itu), Lefebvre berpendapat bahwa produksi sosial atas ruang - kota adalah dasar bagi reproduksi masyarakat yang disebabkan oleh kapitalisme. Jadi, dalam hal ini, dikesankan bahwa kapitalisme adalah segalanya. Sesungguhnya, apa yang dimaksud dengan ruang dalam pemikiran Lefebvre? Ruang (sosial) adalah produksi social - ruang diproduksi sebagai cara tertentu yang menjadi alat berpikir dan bertindak. Ruang tidak hanya berarti sebagai produksi namun juga sebagai alat kontrol dan untuk kemudian mendominasi (kekuasaan).

(http://id.wikipedia.org/w/indexphp?title=Henri

Lefebvre\&oldid=6668237).

Demikianlah, ruang menjadi sangat elastis dalam pemikiran Lefebvre.
Ruang dapat dibentuk dan membentuk dirinya sendiri, tidak sebagaimana yang kita bayangkan. Di sini pun kita melihat bahwa ruang pada gilirannya dapat mempengaruhi kekuasaan atau kebijakan serta di sisi lain dapat berkembang ke arah kapitalisme itu sendiri.

Lebih lanjut, Lefebvre berpendapat bahwa seluruh masyarakat dan semua model produksi-menghasilkan ruang tertentu --- ruang tersendiri. Dalam hal ini, dimisalkan, kota dimasa lampau tidak bisa dimengerti dan mungkin juga dipahami dalam kelompok sederhana dari manusia dan benda-benda dalam suatu ruang kota. Ruang - kota memiliki praktik ruangnya sendiri berbeda dari yang dipahami. (yang cocok bagi kota, Lefebvre menyatakan bahwa iklim intelektual terkait erat dengan produksi sosial pada keruangannya). Jadi, Lefebvre ingin mengatakan bahwa ruang dengan sendirinya diproduksi oleh masyarakatnya sendiri. Ruang, jika begitu menunjukan keberadaannya dan masyarakat pengelolanya. Sementara, bagi yang tidak masuk dalam 
kelompok menjadi terasing dan abstrak.

Dalam hubungan dengan marxis, Lefebvre mengatakan bahwa ruang pertama (ruang fisik atau ruang persepsi), adalah praktis spasial dari :

1. Ruang Pertama (ruang fisik atau ruang yang dipersepsikan) "ruang praktis dari dirahasiakan masyarakat, yang memiliki ruang itu; mengusulkan dan menyangka tentang ruang, di dalam interaksi dialektikal; ruang diproduksi secara pelan dan dijamin sebagai ruang utama dan dimiliki secara tidak sah".

2. Ruang Kedua (Ruang Mental atau ruang yang diterimakan) ruang dikonseptualisasikan, sebagai ruang keilmuan, perencanaan, urbanisasi, teknokratik, dibagi - bagi dan sosial engineering, sebagai tipe penting dengan suatu keilmuan yang diarahkan - seluruh dari yang memiliki identitas apa yang dihidupkan dan apa yang dipersepsi dengan apa yang diterima".

3. Ruang Ketiga (Ruang Sosial atau ruang yang dihidupkan) "Ruang yang secara langsung diterima sebagai image yang diasosiasi dan yang disimbolkan".
Demikian gambaran ruang untuk diaplikasikan dalam kehidupan. Artinya, setiap pemikir tinggal memilah dan memilih sesuai dengan apa yang dipikirkannya.

Selanjutnya, hubungan dengan marxis, di mana ruang sosial berhubungan dengan produksi yang diproduksi kembali dan yang dialetik kontradiktif dengan interaksi 3 faktor hingga memunculkan jenis-jenis ruang. Ruang, dinyatakan:

- Oleh "Ruang Praktis" diartikan ruang sebagai direproduksi setiap saat dalam kehidupan sehari - hari.

- Oleh "Representasi Ruang”, diartikan ruang sebagai membangun secara kognitif.

- Dan oleh "Ruang Representasi," oleh Lefebvre diartikan sebagai simbolisasi yang kompleks dan ruang idealisasi”.

Inilah, paling tidak, gambaran Lefebvre tentang ruang. Dalam pandangan Lefebvre sejak tahun 70an, produksi ruang menghasilkan suatu ruang non-refleksi setiap hari 
ditambah dengan alinasi, dominasi langsung dari konsep abstrak matematika dari ruang, dan direproduksi di dalam ruang praktis. Lefebvre melihat suatu garis penjelas tentang dialinasi dalam ruangrepresentasi dengan catatan bahwa non-dialinasi, mitikal, pra-modern atau artistik visi tentang ruang. Teori spasial marxis sudah memberikan dorongan keistimewaan baru oleh David Harvey, di dalam terutama, siapa yang tertarik dalam efek transisi Fordism menuju "akumulasi fleksibel" dalam pengalaman ruang dan waktu.

Dia memperlihatkan bagaimana variasi inovasi pada bidang ekonomi dan level teknologi sudah dilanggar krisis - rerata dalam fleksibilitas dari sistem Fordis, dus kemunculannya rerata terbalik dari modal. Kasus ini sudah diakselerasi secara umum dalam siklus ekonomi. Menurut Harvey, hasilnya adalah "kompresi ruang-waktu". Sementara perasaan untuk tema yang panjang, ke depan, berlanjut akan hilang, hubungan antara dekat dan menjadi lebih berjarak dan sulit untuk ditentukan (From Wikipedia, the free encyclopedia).

\section{Ruang Dalam Arsitektur Moderen}

Untuk itu,maka dilakukan percobaan menempatkan ruang dalam arsitektur, terutama dengan arsitektur modern agar memudahkan pokok pokok pikiran Lefebvre, yang selama ini, telah berkembang kian - kemari. Dalam arsitekturmodern banyak yang masih menjadi misteri, ketimbang arsitektur tradisional, yang dalam banyak hal, arsitektur tradisional dimana kasus - kasus sudah banyak terungkap, teratasi, dan ketinggalan zaman serta yang paling krusial adalah tidak efisien dari sisi biaya dan waktu. Sosiologi arsitektur klasik, dipandang oleh masyarakat sekarang dalam batasan tertentu telah kuno dan klasik. Paling tidak, tokoh tokoh yang digambarkan telah dapat memberikan acuan bahwa sosiologi pun dapat menjelaskan ruang di dalam disiplin - disiplin lain. Hanya saja perkembangannya mungkin tertatih - tatih dan mungkin saja terlunta - lunta hingga akhirnya tidak dihargai dan dihormati.

\section{Padahal filosofi yang} berkaitan dengan arsitektur bisa saja terabaikan dan tidak digunakan. Untuk kasus Indonesia seperti yang 
kita lihat, hampir dipastikan tidak kita temukan lagi kecuali ada orang yang sedang memburunya sebagai barang antik. Atau mungkin juga sebagai simbol kekuasaan dan status dibandingkan dengan yang lainnya. Tidak dipungkiri, memang buruan demikian dalam batasan tertentu ada yang diaplikasikan dalam bentuk rumah tinggal misalnya. Tetapi, sebagian besarnya, tentu tidak. Hanya mungkin orang setengah gila, yang bersedia rumah tinggalnya dibuat macam - macam. Mereka tidak hidup sendiri tetapi dengan istri dan anak anaknya, hingga belum tentu sepaham serta satu pengertian.

Dewasa ini orang kembali ke alam raya untuk menggali kembali arsitektur tradisional itu. Jika ingin. Perkembangan demikian, nampaknya sudah cukup. Sementara dalam arsitektur modern serta kekinian, jauh lebih kompleks dan komprehensif, dengan kemajuan serta perkembangan itu. Lefebvre tidak berubah dalam konsep - konsep dan tingkah laku dalam menyikapinya. Dalam berbagai konsep dan teori, Lefebvre tetap kukuh dengan pendirian dan tidak bergeming dalam perubahan - perubahan kekinian yang ada, termasuk metode serta analisisnya. Di sinilah kemudian para pemikir mencoba memasukkan Lefebvre ke dalam kubu Marxis.

Dalam arsitektur modern, karena Lefebvre menempatkan ruang sebagai barang hidup yang bergerak kian-kemari ; sehingga buat yang memahami mirip relativitas Einstein, yaitu ketika seseorang naik kereta api dan yang lainnya ikut naik tetapi terus berlarian mengikuti di dalam gerbong - gerbong kereta api yang ditarik lokomotif. Orang yang berlarian di dalam gerbong dibanding dengan orang yang tetap berdiri di luar kereta api maka akan tetap dihitung bersamaan, itulah yang dinamakan relativitas. Dahulu, pergerakan orang tersebut tidak dihitung; tetapi kini, dengan kemajuan yang ada, semua orang yang terlibat ikut diperhitungkan. Sehingga akan kelihatan perbedaan - perbedaan, untuk kemudian diperhitungkan ulang.

Dalam hubungan ini Lefebvre pun demikian adanya. Mirip Einstein. Dia memahami dan mengerti pergerakan - pergerakan itu di dalam pikiran - pikirannya. Hampir semua pokok - pokok pikirannya berkutat 
seperti itu. Berikut, arsitektur modern untuk pertama kali dimulai masa revolusi indutri (Inggris). Nampaknya, revolusi industri sebagai acuan para pemikir dalam menempatkan seseorang masuk ke dalam kubu mana. Memang masih banyak ukuran - ukuran yang lain, tetapi revolusi industrilah yang paling banyak digunakan oleh para pemikir untuk menentukan Batasan - Batasan akademik. Seperti kita lihat, penemuan - penemuan ketel uap, telepon, bola lampu, telegraf dan lain sebagainya ditemukan dimasa revolusi industri. Secara sosiologis, kaum kaya yang bermukim di perkotaan dengan fasilitas lengkap, penuh kemewahan; sementara kaum miskin juga tinggal di perkotaan yang sama tetapi dengan fasilitas apa adanya, sehingga lambat - laun memungkinkan kaum miskin tadi tersingkir, terdepak dan masuk di celah - celah perkotaan tadi.

Akibatnya, mereka menciptakan pemukiman tersendiri dan umumnya tidak teratur, angka kriminal yang tinggi, reproduksi yang apa adanya, sehingga dengan kondisi - kondisi yang demikian bisa diduga hasil kerja mereka sangat terbatas, tertutup, menjadikan pertumbuhan penduduk tidak sehat, kenakalan remaja yang mengalami kenaikan dan lain sebagainya. Dengan tanpa memperhatikan bentuk dan karya karya rumah mereka sendiri, sepanjang bisa bertempat tinggal atau bermukim. Cukuplah sudah. Revolusi industri ini kemudian bergerak menyusul di daratan Eropa yaitu di Perancis, Jerman, Italia, Belanda, Rusia, dan Hongaria.

$$
\text { Menurut Kolb (1990), }
$$

konsekuensinya, di abad ke-19 pergerakan - pergerakan demikian telah terjadi. Lebih lanjut, demikian Kolb, sekaligus untuk melawan historizing atau 'penggunaan bentuk - bentuk bersejarah' dan menyetujui seta menyepakati bahwa arsitektur harus mengungkapkan gelora 'semangat' dan antusias dari para arsitek. Sebuah bangunan modern harus mengikuti acuan gaya - gaya masa lalu (historical style) dan kembali kepada pikiran - pikiran dan perasaan - perasaan manusia. Dengan demikian, bangunan itu harus "benar, logis, dan bersih dari kebohongan". Logika begitu haruslah dipahami sebagai sebuah bentuk dan konsep konsep yang dibangun di dalam 
ruang. Mungkin saja sikap - sikap demikian dapat muncul dan ada benarnya.

Demikianlah gambaran umum yang mungkin saja dikehendaki oleh masyarakat pada masa itu. Lefebvre dalam menyikapi hal yang demikian, merupakan suatu yang wajar dan biasa - biasa saja, mengingat setiap orang selalu mengalaminya. Bahwa sikap - sikap yang demikian, di mana ruang atau bidang perlu diberi makna dan diperluas pengertiannya, yaitu : pertama, representasi ruang adalah yang meliputi produksi dan reproduksi ruang. Melapisi, membingkai dan pada akhirnya mendominasi praktik ruang. Ruang dalam posisi ini, bergerak dan tidak diam. Seperti yang diungkap, bahwa ruang itu bernyawa dan hidup.

Sementara, ruang yang kedua, adalah cara - cara ideasional dengan maksud agar kuat untuk membahas ruang agar lebih optimistik-inovatif. Kondisi dan pikiran ini menyamai ide atau gagasan Marx mengenai sifat spesies, dia mengatakan dengan apa yang dikatakan Marx sebagai ruang mutlak atau ruang alamiah (contoh, wilayah - wilayah "hijau") yang secara sengaja tidak dihuni manusia, dibuat tidak otentik, atau dihancurkan oleh kekuatan - kekuatan ekonomi dan politik. Ruang abstrak, seperti representasi ruang, ruang abstrak adalah ruang dari sudut pandang suatu subjek abstrak seperti seorang perencana atau arsitektur perkotaan. Jenis ruang yang baru sama sekali.

Akhirnya, ruang yang ketiga yaitu dari tipe - tipe ruang yang didiskusikan disini, ialah ruang diferensial adalah yang memulihkan dan memperbaiki kesatuan yang ada. Lagi, Lefebvre mengatakan jauh lebih banyak hal tentang ruang yang dia kritik daripada alternatif yang diharapkan (Ritzer, 2012: 528) terjadi. Untuk sementara, ruang setidak-tidaknya seperti yang dikemukannya.

Sementara secara definisi tentang ruang, diartikan suatu sub-disiplin dari sosiologi yang membawa sebagian besar untuk membangun teori - teori termasuk disiplin geografi, termasuk sub lapangan sub lapangan dari geografi manusia, geografi ekonomi, dan geografi feminis. Sebagaimana diungkap, bahwa definisi ruang itu kompleks dan berdimensi banyak. Lihat saja, ruang adalah satu dari konsep 
kepentingan terbesar dalam disiplin ilmu sosial sebagai sesuatu dasar menuju pengertian kita tentang geografi. Tema "ruang" sudah didefinisikan secara bervariasi oleh pemikir; di dalam tema umum. Sedangkan, the Oxford English Dictionary mendefinisikan ruang dalam dua cara;

1. Suatu kelangsungan ektensi dipandang, dengan atau tanpa referensi menuju keberadaan dalam objek.

2. Interval antara titik atau objek dipandang sebagai keharusan dari dimensi satu, dua atau tiga.

Bagaimana pun, 'geografer manusia' tertarik di dalam objek tentang ruang dan posisi relatif mereka, yang melibatkan deskripsi, penjelasan dan prediksi dari distribusi fenomena.

Dus, hubungan antara objek di dalam ruang adalah pusat studi (Http:// id.wikipedia.org/w/index-

php?title=Henri

Lefebvre\&oldid=6668237).

Bagaimana dengan arsitektur modern? Lefebvre, lagi-lagi tidak terlalu banyak membicarakannya atau mendiskusikan. Baginya, cukup mengenai ruang demikian saja, yang saling berdialektik satu dengan lainnya. Ada dialog antara mereka, sehingga bakal ditemukan hal yang baru sama sekali atau tambahan yang mungkin tidak pernah kita perhitungkan sebelumnya. Di sini, sebenarnya, arsitektur modern telah muncul sekitar 150 tahun yang lalu.

Selama itu, arsitektur modern masih bersifat apa adanya dan bersahaja dalam memberikan respon pada setiap perkembangan di sekitar serta membandingkan dengan kehidupan - kehidupan yang jauh di luar sana bahkan di belahan dunia lain. Di sinilah, sangat tergantung dari rancangan pembuatnya. Sehingga banyak yang mengatakan, bahwa tidak berkembang, statis, tidak inovatif dan secara evolutif kemajuan - kemajuannya sangat lambat dan lain sebagainya ; sampai pada era terakhir. Artinya, arsitektur modern sempat mati suri, galau, kehilangan orientasi atau kritik - kritik yang mendalam dan komprehensif serta penuh dengan gambaran - gambaran yang menyesatkan terhadap arsitektur modern itu.

\section{Sejarah Arsitektur Modern}


Arsitektur modern ini oleh para pemikir dimulai dari karya Kolb (1990). Dia mengatakan, arsitektur modern telah mempropagandakan dirinya abad ke-19 dengan menyetujui ide bahwa, arsitek harus memunculkan dirinya dan, kalau ingin berhasil (dalam arti diakui masyarakat) haruslah menyesuaikan diri dengan gaya atau kehidupan masyarakatnya. Tidak mungkin kita membuat sesuatu yang berbeda. Berbagai aturan dalam kehidupan sosial dari masyarakat yang bersangkutan. Artinya, kita harus menyesuaikan dengan keinginan masyarakat, meski di sana - sini, ditambah atau dikurangi, bagian bagian yang penting atau tidak penting menurut masyarakat, sejauh tidak urgen atau penting. Ada hal - hal pokok yang utama dalam pendirian rumah misalnya ; tidak dihilangkan sama sekali,kalau dihilangkan sama sekali tentu bukan rumah namanya. Justru dilengkapi dan dibuat makin baik secara estetika maupun kekuatannya.

Bahkan belakangan ini mulai berkembang ke arah yang sulit dimengerti oleh para arsitek. Artinya, sepanjang ada unsur efisiensinya masyarakat akan menerima dengan antusias. Mungkin bagi sementara orang tidak benar terutama yang datang dari masyarakat kelas atas. Bagi masyarakat kelas atas tentu kemewahan menjadi hal utama dan juga segala fasilitas penunjang tidak terlalu jauh dari rumah tinggal. "kalau bisa segala sesuatu itu ada di sekitar tempat tidur, sekali melek semua telah tersedia". Dengan kata lain, masyarakat kelas atas itu memiliki selera yang tidak sama. Itulah, Henri Lefebvre nama lengkapnya, lahir dari keluarga bersahaja di Hagetmau, Landes, Perancis, pada 16 Juli 190129 Juni 1991

(http://id.wikipedia.org/w/indexphp?title=Henri Lefebvre.oldid= 6668237). Mencoba menyesuaikan keinginan - keinginan masyarakat sesuai dengan kondisi fisik bangunan dan sosial yang ada di sekitarnya. Mungkin saja dibelahan bumi yang lain akan berbeda pula, sejauh bisa ditemukan dibelahan bumi itu. Kecuali memiliki dana yang cukup, dapat mendatang dari belahan bumi lain.

Lebih lanjut dikatakan, arsitektur modern itu tidak menginginkan ide - tipe yang 
beraneka. Ide - tipe ini tunggal, unik dan langka sifatnya. Padahal dengan arsitektur modern, kalau kita memahami, sungguh memiliki dimensi ganda atau banyak dan umumnya akan sulit mengikutinya. Dimensi - dimensi ini berguna untuk mensiasati perkembangan arsitek dewasa ini. Katakanlah, berarti dan bermakna. Tetapi jika kita kembangkan lebih lanjut, sekali lagi, terutama bagi masyarakat kelas atas, yang dananya berlimpah - ruah, mungkin tidak menimbulkan masalah ; sepanjang enak dipandang mata, luas bangunannya dan harmonis bagi penghuninya. Mungkin tidak terlalu fungsional.

Artinya, kita harus tahu terlebih dahulu kemampuan masing masing pihak. Berbeda halnya dengan kelas bawah dan begitu seterusnya. Setiap perkembangan arsitektur modern itu disesuaikan dengan perkembangan masyarakat kelas bawah itu sendiri, dan pada akhirnya perkembangan zamannya. Demikian yang dikatakan oleh sebagian orang, bahwa oleh perkembangan arsitektur modern itu berkembang seirama dengan masyarakatnya. Artinya, seluruh masyarakat manusia mengikutinya.

Pada tahap lanjutan, arsitektur modern mewujudkan kejelasan struktur dengan cara menghapuskan kisah - kisah lama (dianggap ketinggalan zaman). Arsitektur modern merupakan seni tersendiri yang tertarik untuk memasuki penemuan - penemuan di bidang sains. Penolakan arsitektur modern terhadap ornamen, teknologis, dan sainstis, yaitu penolakan terhadap ornamen merupakan seni dan ideologi tersendiri. Dalam penemuan baru itu, industri kaca dan baja merupakan satu bentuk material baru yang juga membuka tahapan yang menciptakan konsep - konsep ruang yang baru. Kaca, khususnya baja telah mulai digunakan pula manfaatnya.

Mungkin pemakaian baja ini seiring dengan makin habisnya kayu (glugu) di hutan - hutan tropis kita, sehingga tidak ada jalan lain buat menggantikannya seirama dengan pembuatan baja yang tidak terlalu berat bagi rumah tinggal (baja ringan). Kita tidak tahu, apakah kedepannya, baja ini nantinya akan menjadi komoditas utama, semua itu sangat tergantung dari masyarakat 
kelas atas dari masyarakat yang bersangkutan. Pasalnya semua itu sangat tergantung dari masyarakatnya. Dalam "The Production of Space" Lefebvre menulis, ruang kota adalah dasar bagi reproduksi masyarakat, disebabkan oleh kapitalisme. Oleh karena itu, konsep hegemoni yang diungkap oleh Antonio Gramci digunakan sebagai referensi untuk menunjuk bagaimana produksi sosial dari ruang nantinya diprakarsai oleh kelas hegemoni atau kelas atas sebagai alat untuk mereproduksi dominasinya.

Maksud dari semua itu sudah terlihat sejak 50 tahun belakangan ini, bahwa kelas bawah berbondong bonding mereplikasi dan mencontoh begitu saja bentuk rumah atau bangunan kelas atas,tanpa reserve. Bagi kelas bawah dengan keberhasilan mencontoh dan mereplikasi rumah atau bangunan dari masyarakat kelas atas maka dengan sendirinya status social ekonominya akan terangkat mirip dengan kelas atas itu dan akan mendapatkan pujian maupun idola dari kelasnya sendiri. Itu satu bentuk hegemoni dari kelas atas ke kelas bawah tanpa disadari kelas bawah itu sendiri. Misalnya, apakah menu makanan keseharian kelas bawah itu akan menyamai kelas atas.

Sulit untuk mengatakannya. Mungkin dari kesehatan dan reproduksi akan jauh sekali perbedaannya. Apakah kelas bawah akan ke dokter lazim kalau memeriksakan diri seperti yang dilakukan kelas atas atau sakit sedikit saja sudah harus ke dokter. Kelas bawah mungkin tidak berobat ke rumah sakit, paling berobat sendiri atau herbal maupun ke dukun. Artinya, cukup membiarkan begitu saja, nanti akan sembuh sendiri atau kalaupun ingin memeriksakan dirinya ke dokter cukup ke Puskesmas terdekat. Rasanya akan sulit kita temui kelas bawah akan memiliki dokter pribadi. Sangat beruntung, sekarang, di setiap kecamatan telah didirikan Puskesmas maupun Puskesmas pembantu. Dan masih banyak contoh lainnya.

Hanya saja semua itu sangat tergantung dari masyarakat pemakainya. Arsitektur modern dengan begitu, bersifat relatif dan potensi perkembangan cukup sebagai dasar inovasi baru. Edward Soja (1989) misalnya, sangat dipengaruhi 
oleh Foulcoult maupun Lefebvre sendiri ; seperti Foucoult dia mengkritik fokus soal waktu sebagai hal yang menciptakan "historisisme carceral" dan suatu "rumah penjara sementara". Mungkin, Soja berusaha menggabungkan studi geografi dengan studi waktu. Gambaran ini, tentu saja, membuktikan bahwa Lefebvre mempunyai pengaruh kuat dan mendalam pada pemikiran Soja. Mungkin inti pemikiran teoritis Soja bagi pengertian kita atas ruang adalah idenya mengenai trialektika.

Kontrasnya perspektif ruang "ruang kota menjadi lebih merupakan arena mental atau ideasional, yang dikonseptualisasi di dalam tamsil, kata Ritzer (2012 : 531), pemikiran refleksif, dan reprentasi simbolik, suatu ruang yang dipahami dalam imajinasi, atau ... khayalan urban (Gans, 2002). Contoh dari suatu perspektif ruang meliputi peta - peta mental yang kita bawa serta, visi visi mengenai utopia urban, dan metode - metode yang lebih formal untuk memperoleh dan menyampaikan informasi tentang geografi kota. Itu pembahasan Lefebvre terhadap para pengkritiknya. Buku "The Survival of
Capitalism" yang ditulisnya, tidak lain adalah untuk menjawab para pengkritiknya sekaligus eksistensi dirinya di dunia akademik yang ditekuninya.

\section{Kesimpulan}

Henri Lefebvre sebenarnya, relatif, sama sekali kurang banyak membicarakan soal ruang unsich. Ruang selalu dihubungkan dengan segala sesuatu yang lain. Soalnya, ruang baginya berdimensi banyak dan kompleks. Hal yang banyak dan kompleks tadi, kalau mau diterjemahkan,di dalamnya akan sangat banyak pengaruhnya bagi yang lain. Seperti kata dia lebih lanjut, ruang bersifat dialetik dan hidup layaknya manusia serta makhluk lain yang bernyawa. Dalam posisi inilah, jika kita cermat dan lebih teliti dalam bersikap tentu tidak akan terjerumus pada tempat yang tidak bersesuaian dengannya. Tetapi sebaliknya, hancur dan tidak bersesuaian dengan kondisi sekarang. Seperti kata dia tentang : ...Ubah Kehidupan! ...Ubah Masyarakat! tentu orang akan sulit menerjemahkan apa yang dimaksudkannya. Tetapi bagi pemikir tertentu, langsung dapat menebak 
dengan tepat Lefebvre masuk dalam kubu mana, setelah melihat pemikiran - pemikirannya bahwa Lefebvre adalah bagian dari kubu marxis.

Padahal baginya, tidak lain untuk mengulas dan membahas apa yang dinamakan dengan konsep ideologi dan konsep budaya yang dikaitkan dengan kenyataan sosial yang ada. Konsep ideologi dan konsep budaya dimaksud, untuk mengungkapkan budaya dalam arti yang sesungguhnya sehingga mudah diterjemahkan oleh orang awam. Dengan cara berpikir seperti itulah, dia masuk dalam kubu neo-Marxian. Sementara ada yang mengatakan, ruang itu tidak bergerak, mati dan stabil, dikelompokkan dalam kubu yang sebaliknya. Jika ruang itu hidup dan berdialektik maka dengan sendirinya memberikan peluang pada dirinya untuk segera bersikap dan memilih serta menyesuaikan dengan perkembangan - perkembangan yang terjadi. Setidaknya, dengan cara menempatkan posisi kepada rezim kapitalis, sosialis atau sosio religious dan lain sebagainya. Dengan cara ini, Lefebvre berupaya menempatkan ruang apa adanya seperti halnya kubu yang sama dengannya itu.
Soal, arsitektur modern oleh Lefebvre ditempatkan dengan apa adanya dan ruang diletakkan di dalam arsitektur modern itu sendiri, yang mau tidak mau, setiap para pemikir sedikit dibuat bingung dengan pemikiran pemikirannya ; sehingga bagi para pemikir lain justru berpikir sebaliknya. Mungkin, tidak ada yang bersikap netral dan berimbang dalam menyikapi pemikiran - pemikiran yang dikemukakan Lefebvre. Paling tidak, ada yang miring ke kiri maupun kanan. Tetapi, itulah Lefebvre dengan segala kelebihan maupun kekurangannya. Yang terpenting dari itu semua adalah kemampuannya dalam mempengaruhi para pemikir lain dan Lefebvre sendiri mempunyai pengikut yang menggandrungi pemikiran - pemikirannya itu. Terlepas dari persetujuan kita, bahwa Lefebre memang seorang idealis dalam mengejar berbagai keinginan, sehingga pemikiran - pemikirannya kelihatan begitu liar dan kesana kemari. Padahal Lefebre sedang bereksperimen bahwa ilmu yang bagaimana pun dahsyat dan terkenalnya tentu membutuhkan ilmu - ilmu lain. Tak pernah ada, ilmu yang dapat bergerak dan berdinamika 
sendirian dalam mengungkapkan realitas sosial itu.

\section{DAFTAR PUSTAKA}

Gans, Herbert, J (2002). City and Community 1: 4 December American Sociology Association, 1307 New York Avenue, NW Washington, DC 2005-4701

Http://id.wikipedia.org/w/indexphp?title=Henri Lefebvre\&oldid $=6668237$

Http://en.wikipedia.org/wiki/Sociolo gy_of_architecture\#Classical_Sociology_of _architecture

Kolb, David (1990), Posmodern Sophistication, Chicago da London. The University of Chicago Press

Ritzer, George (2012), Teori Sosiologi, Pustaka Pelajar. Yogyakarta

Wikipedia Sociology of Architecture, the title encyclopedia

Wikipedia, the free encyclopedia 